\title{
Cystic duct necrosis, as a laparoscopic finding
}

\author{
Alejandro Vela, Gilberto Gerardo Ortiz Cantu, Alberto Robles Méndez Hernández, \\ Carolina Guadalupe Castillo Rodríquez
}

Surgery, Hospital Angeles Metropolitano, Mexico City, Mexico City, Mexico

\section{Correspondence to} Dr Alberto Robles Méndez Hernández:

albertormh01@gmail.com

Accepted 7 January 2021
Check for updates

(c) BMJ Publishing Group Limited 2021. No commercial re-use. See rights and permissions. Published by BMJ.

\begin{tabular}{|l|}
\hline To cite: Vela A, \\
Ortiz Cantu GG, \\
Robles Méndez Hernández A, \\
et al. BMJ Case Rep \\
2021;14:e239340. \\
doi:10.1136/bcr-2020- \\
239340 \\
\hline
\end{tabular}

\section{DESCRIPTION}

An 88-year-old female patient presents with 72 hours of dull right upper quadrant pain after a fatty meal and gastric like emesis. Previous medical record of hypertension, left haemicolectomy due to colon cancer and hysterectomy. Arriving with tachycardia of 105, blood pressure of 130/70 and $35.5^{\circ} \mathrm{C}$. At physical examination, she presents hyperalgesia and hyperesthesia, pain at palpation of right upper quadrant and positive Murphy's sign. Laboratory tests with haemoglobin of 16.8 , leucocytosis 25.800 with neutrophilia $87 \%$, procalcitonin 2.64 , C reactive protein 18.4 , glucose 159 , total bilirubin 1.63, lactate dehydrogenase 418 , rest within normal range. Abdominal ultrasound with acute cholecystitis, probably hydrocholecyst. Laparoscopic approach to cholecystectomy with multiple adhesions and pericholecystic inflammatory process, biliary leakage to the peritoneum and a gangrenous gallbladder (video 1). After dissection of hepatocystic triangle and achieving critical view of safety a necrotic cystic duct is identified

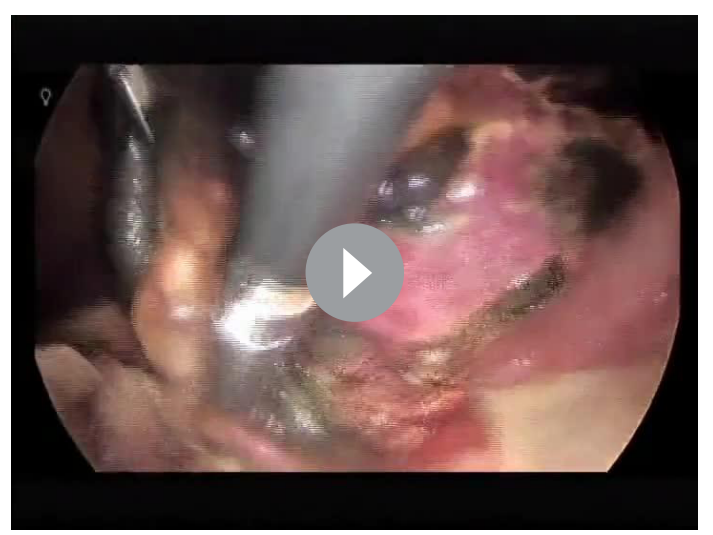

Video 1 Surgical video a large, distended, gangrenous gallbladder with multiple epiploic-gallbladder and epiploic-abdominal wall adhesions and bile peritoneal fluid, a necrotic duct in all its extension to the cholecochal junction and management with three staples proximal to cholecochus. We can observe a necrotic duct in all its extension to the cholecochal junction and management with three staples proximal to cholecochus.

\section{Learning points}

A totally necrotic cystic duct must be approached as a probable Strasberg A biliary leak.

- On elderly patients, 'do no harm' and do not intend primary closure, better leave a drain.

into choledochal junction. We decide to manage the necrotic cystic duct by leaving three proximal staples before section of the duct and leaving a drain because of non-viable tissue. After 10 days postsurgery, we remove the drain and on 6 months follow-up no biliary fistula was developed.

Woods et al described leak from a necrotic of the cystic duct proximal to the endoclip maybe by capacitive coupling injury or by a secondary process due to an impacted cystic duct stone or severe inflammation, in this case, the evidence of tissue damage was evident so measures were taken in order to prevent cystic duct leak. ${ }^{1}$ Strasberg classification A is defined as cystic duct leak or small leaks from liver bed, we took this evidence to prevent this imminent condition because of tissue unviability leaving three staples and drainage to follow possible fistula and opportunely treat with common bile duct endoprosthesis by cholangiopancreatography endoscopic. ${ }^{2}$

Contributors ARMH, AV, CGCR and GGOC worked on patient attention and writting of the article.

Funding The authors have not declared a specific grant for this research from any funding agency in the public, commercial or not-for-profit sectors.

\section{Competing interests None declared.}

Patient consent for publication Obtained.

Provenance and peer review Not commissioned; externally peer reviewed.

\section{REFERENCES}

1 Woods MS, Shellito JL, Santoscoy GS, et al. Cystic duct leaks in laparoscopic cholecystectomy. Am I Surg 1994;168:560-5.

2 Pesce A, Palmucci S, La Greca G, et al. latrogenic bile duct injury: impact and management challenges. Clin Exp Gastroenterol 2019:12:121-8. 
Copyright 2021 BMJ Publishing Group. All rights reserved. For permission to reuse any of this content visit https://www.bmj.com/company/products-services/rights-and-licensing/permissions/

BMJ Case Report Fellows may re-use this article for personal use and teaching without any further permission.

Become a Fellow of BMJ Case Reports today and you can:

- Submit as many cases as you like

Enjoy fast sympathetic peer review and rapid publication of accepted articles

Access all the published articles

Re-use any of the published material for personal use and teaching without further permission

Customer Service

If you have any further queries about your subscription, please contact our customer services team on +44 (0) 2071111105 or via email at support@bmj.com.

Visit casereports.bmj.com for more articles like this and to become a Fellow 